\title{
54 RISK-MANAGEMENT OF PRODUCT DEVELOPMENT IN NON-HIERARCHICAL REGIONAL PRODUCTION NETWORKS
}

\author{
A. Gerber ${ }^{1}$, K. Althaus ${ }^{1}$, M. Dietzsch ${ }^{1}$, \\ D. Weidlich ${ }^{2}$, Ralf Steiner ${ }^{2}$ \\ Chemnitz, University of Technology, anna.gerber@mb.tu-chemnitz.de \\ GERMANY
}

\begin{abstract}
Co-operation in non-hierarchical networks is a newly developed approach to value adding in small and medium-sized enterprises. The special research program No 457 ( promoted by the German Foundation for research DFG) investigates pools of units of competence, which can be integrated equally into various areas of value adding. The following article concentrates mainly on the planning areas like product development in non - hierarchic networks. Due to the shared competencies the risk assessment poses a particular problem in networks of that kind.
\end{abstract}

\section{INTRODUCTION}

Employers, innovators and trainers, small and medium-sized businesses form the backbone of German economy. Despite partially comprehensive expertise, these companies lack sufficient resources to produce complex and innovative products independently and in a consumer-oriented manner. By co-operating with each other, supplement deficient resources and competencies are shared.

However, usually such co-operations are hierarchically structured. Internally, decision authorities at executive levels are missing. Externally, large and economically strong partners are too dominating. Though weaker co-operation partners benefit from the relative stability of the partnership, they have to put up one-sided dependencies and are missing direct access to the end consumer.

Moreover, newly founded companies are hardly able to approach co-operative relationships already established. This means, potentials and competencies are wasted. The economically aspired foundation and development of small and medium-sized companies is obstructed.

Increased direct co-operation between small-sized businesses and business units can remedy this situation. They have especially good chances in a regional setting as

\footnotetext{
1 Institute for Production Measuring Technology and Quality Assurance (IFMQ)

2 Institute of Machine Tools and Production Processes (IWP)
} 
existing structural and mental relationships can be utilised here.

The advantages achieved by the lack of hierarchy are opposed by problems. Who decides whether an assignment or project is accepted? For this decision the risks linked to the project have to be recorded and assessed. But how can risks be recorded if participating units of competence are not defined yet?

It will mainly be the product development that has to cope with this task. The quality management will offer support by providing methods and tools such as teamwork, error chain analysis, FMEA and ABC analysis. The following chapter will introduce the basics of the non-hierarchical network and the consequential requirements for risk management.

\section{BASIC OBSERVATIONS}

\subsection{Basics of the Non-Hierarchical Networking}

In the future, entrepreneurs will provide their resources as self-contained competence cells. Competence cells consist of a human being with its individual competencies (characteristics, capabilities, willingness) and available resources (facilities, stocks, equipment). They form the smallest autonomous performance units that are able to work independently. Small and medium sized companies transform into competence cells by special requirements given from the specialist subprojects.

Competence cells result from the synthesis of competence components. A competence framework consists of function-oriented competence cells or competence components from several competence frameworks of process-oriented competence cells. Competence frameworks define certain functions of the business activity and of the value-adding process (e. g. marketing/distribution, product development, process planning, manufacturing, assembly, logistics, quality/service (see figure 1)).

Competence cells form networks - in contrast to previous models - nonhierarchically. This means that inside the company to which the competence cells belong no hierarchical structures are created. Competence cells connect directly to other competence cells. They posses equal rights in decision making.

Network building takes place within a region. "Region" is understood as an economic space with its technical, economic, ecological and social structure defined by specific competencies (e. g. mechanical engineering, microelectronics and mechatronics).

In such a region many competence cells already exist. They are in free competition and link temporarily into the value-adding process to satisfy certain consumer needs. Competence deficiencies are compensated either by founding new competence cells or by external purchases.

The amount of competence cells in a competence network is not exactly defined. A sensible number of competence cells is around 100 cells per network.

If a specific project takes place, special competence cells are chosen for a limited period of time according to the customer order. 


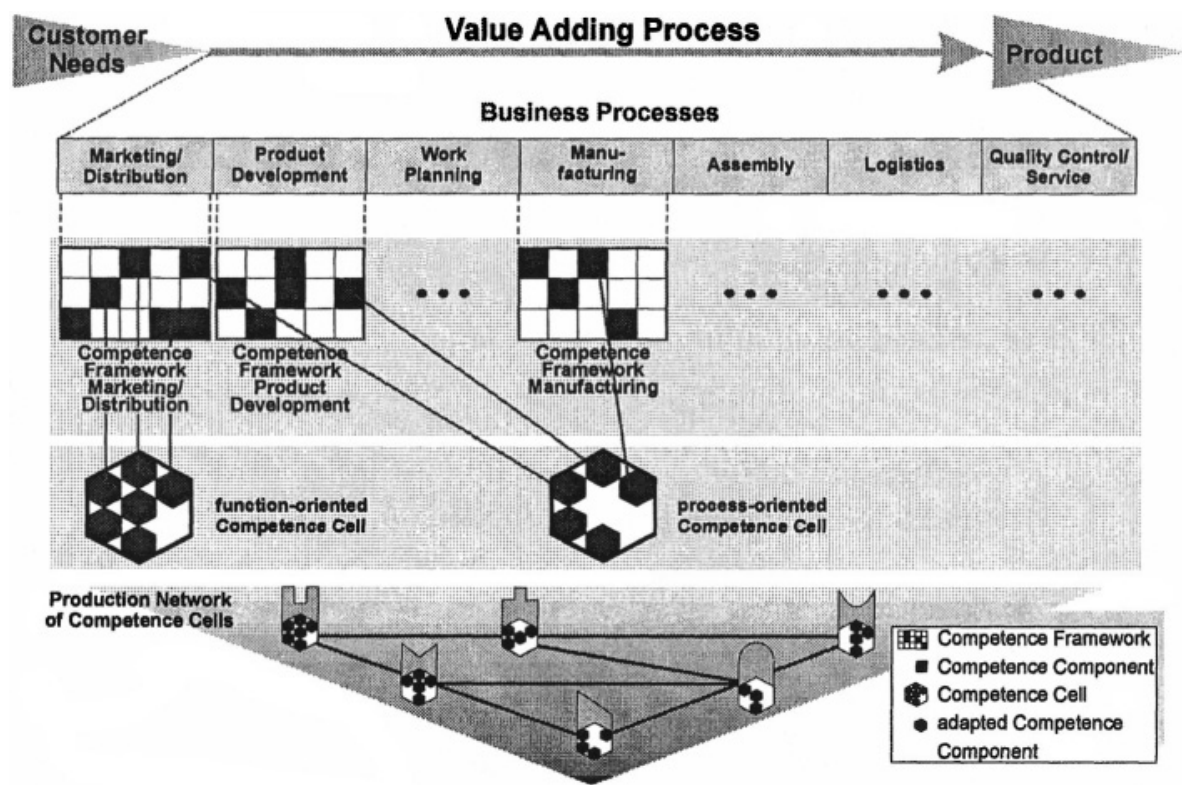

Figure 1 - Connection between competence scope competence components, competence cell, network value-adding process and business activity [5]

\subsection{Requirements for risk management in the Non-hierarchical production network}

A risk is a potential problem, which has not yet occurred and which may lead to anything from delay, or in the worst case to the failure of the whole project.

The possible risks, which may appear in a network due to the lack of hierarchy and the high amount of interfaces, have to be assessed by using different criteria than would be used in a normal enterprise.

The particular requirements for a risk management in a non-hierarchical production network are shown in Table 1.

Risks that are created by legal conditions such as product liability have to be known to the units of competence. In case of problems the units that created the difficulties have to bear these risks. In the risk management of a production network these legal conditions have to be considered as a main issue and they have to be at a information system's disposal. A pool for the provisional damage regulation has to be part of the competence network.

Further problems that bear risks and that can occur during the development of new products in a non-hierarchical network are:

- Insufficient co-ordination between the functions

- Lacking polarisation of the product

- Unexpected technical problems

- unsolved basic issues, e.g. strategy

There are also some advantages in applying risk management in non-hierarchical production networks. The risks are shared by many competence units and because of the high amount of competencies a lot of knowledge about risks in different special 
fields exists, which can be used to minimise the risk. Apart from this an assessment of the social and personnel competencies of the network partners takes place, in order to ensure reliability.

Table 1 - Requirements for the risk management in non-hierarchical production networks

\begin{tabular}{|l|l|}
\hline $\begin{array}{c}\text { Structural approach of the non-hierarchical } \\
\text { network }\end{array}$ & Requirements for the risk management \\
\hline Non-hierarchical organisation & $\begin{array}{l}\text { Risk of the single UoC has to be calculable in order } \\
\text { to create trust }\end{array}$ \\
\hline smallest, autonomous units of competence & $\begin{array}{l}\text { standardized risk assessment, consideration of } \\
\text { interaction of risks }\end{array}$ \\
\hline Self-organisation & $\begin{array}{l}\text { What's the impact of the single UoC on the whole } \\
\text { system? (risks) }\end{array}$ \\
\hline Dynamic, order-oriented networking & Risks have to be analysed before every new project \\
\hline $\begin{array}{l}\text { Development and self-improvement of the } \\
\text { Units of Competence }\end{array}$ & $\begin{array}{l}\text { Provide knowledge basis for possible risks (e.g.. } \\
\text { laws, financial risks, market risks), risk assessment } \\
\text { on the basis of impartial data (no estimations) }\end{array}$ \\
\hline Determination of common aims & $\begin{array}{l}\text { Common understanding of the procedure of risk } \\
\text { management, } \\
\text { Linking of all UoC to the remaining risk, } \\
\text { Aims of the development steps clearly formulated, } \\
\text { Strategic reference of the risk management to the } \\
\text { aims of the network }\end{array}$ \\
\hline High number of interfaces & $\begin{array}{l}\text { High risk of information loss, } \\
\text { working risk management system is more important } \\
\text { than in a hierarchical enterprise }\end{array}$ \\
\hline $\begin{array}{l}\text { Error consequences have a stronger impact } \\
\text { within a network than they have on an enterprise }\end{array}$ & Preventing errors instead of treating errors \\
\hline
\end{tabular}

\subsection{Stages of the risk management}

The risk management consists of risk identification and risk assessment. If the project is accepted despite proven risks, or if the risk analysis took place in a later stage of the product development, measures for reduction or avoidance of the risks have to be taken. Finally, the proven risk is monitored in the following value adding stages

\section{Risk identification:}

The stage of risk identification comprises the systematic and market-oriented finding of all risks that can appear during the development of new products in a nonhierarchical production network.

The number of risks is high and hardly to elaborate. Furthermore, as corresponding systematic do not exist, it is not even guaranteed that the really decisive risks have been identified.

An efficient risk identification therefore has to be marked by clear focus on the procedure. The areas which might create the greatest risks have to be identified by analyses as the project is approaching. In addition to that it is known that projects with certain product criteria or certain environmental situations (e.g. market conditions) tend to show similar risk profiles. It is then obvious that these typical risk areas have to be considered more intensively. In the field of construction, for example, one has to be prepared for risks in project calculation. That is why this 
area should be scrutinised more intensively than other areas in such enterprises. For a structured and focused risk identification it is decisive to find criteria that determine whether there has to be further investigation in a risk area.

As risk management can be compared with aim securing, risks can be categorised according to the following aims:

- strategic risks

- financial risks

- market risks

- risks concerning economical performance

- legal and political risks

For the application of risks on the aims of the enterprise the QFD method can be used. Methods such as brainstorming, scenario analysis and $\mathrm{ABC}$ analysis can be useful for the data collection and data analysis.

\section{Risk assessment}

During the stage of risk assessment the identified risks are classified according to qualitative and quantitative criteria. By doing so one has to consider and integrate the interaction of risks.

The risks are assessed according to their financial consequences and the probability of their occurrence. The risks' effect on the customer is described. It is the description of what the customer perceives and how he reacts on it. There has to be a standardised risk measuring for all units of competence. The FMEA represents a central method for risk assessment.

The risk identification and the risk assessment should not only be realised by the product development, but it should also be completed by the corresponding experts. As the development has been divided into several milestones at this point there will be moderated quality meetings. During these meetings the status of the project is described by an interdisciplinary team. The risk management is part of these quality meetings.

\section{Measures for risk reduction or avoidance}

At this stage the identified and assessed risks are actively directed by measures that can control all important loss potentials. During the creation of an offer such a measure can lead to the cancellation of the project. Nevertheless, due to a high number of competencies this will stay an exception.

Risk minimising measures have to be introduced, so that the risks are tolerable for the non-hierarchical network. In case the risk really does occur there have to be reserves in the competence network. Also the determination of prevention measures should happen in an interdisciplinary team.

The documentation of the remaining risk and the measures connected to it represents an important prerequisite for an efficient risk management. The determined measures and the remaining risk for the units of competence concerned and future projects have to be stored in a central knowledge basis.

\section{Risk monitoring}

In order to provide a constant monitoring of the risk following units of competence have to be informed about the remaining risks accepted by the project. New risks which appear during the project also have to be determined and adjusted properly. 
To avoid additional risks, feedback for the product development it absolutely necessary. The awareness of an active risk control in the competence network must be guaranteed in the culture and principles of the non-hierarchical network. The risk management has to be integrated in the project stages of the product development by construction guidelines.

\section{RISK MANAGEMENT IN THE PRODUCT DEVELOPMENT PROCESS}

The product development process in non- hierarchical production networks covers the main stages of Start-Up, planning, concept, design, detail design and the development of prototypes. Here, virtual reality (VR) is a useful tool that can be used to reduce the risk in the development process (Fig. 2). In contrast to hierarchical structures there is no person responsible for projects who decides about the distribution of development tasks according to the respective assemblies.

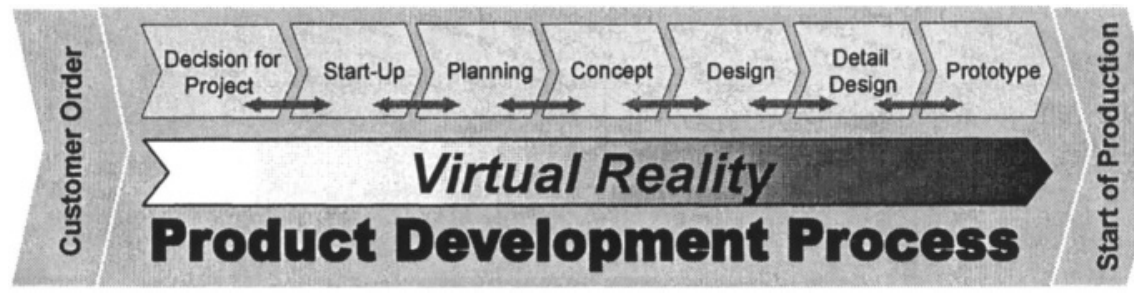

Figure 2 - Product development process

The decision for or against the project is made by marketing and product development competence cells. In a systematic assessment the customer requirements are evaluated.

Based on the requirements list, competence cells are linked with each other temporarily to a product development Start-Up. The Start-Up serves as a basis for both defining the requirement vectors and selecting the required competence components.

A possibility for linking these is the interaction of the function-oriented competence cells of marketing (M), product development (PD), process planning (PP), manufacturing (MF) and quality management (QM). The result of product development Start-Up contains the drawn-up customer requirement, specifications including the precise determination of requirement vectors for generating a nonhierarchical network [3].

In the individual product development phases it becomes evident that there is a discrepancy between the possible exertion of influence on product features and the required product modification costs. The further the development process progresses, the more difficult and costly it is to carry out specific changes to the product properties. Due to the immense costs involved in carrying out changes during the final product development phase, certain shortcomings related to product parameters that do not affect the product function are not corrected.

The starting-point for initiating a product development in a non-hierarchical network is a customer inquiry (Fig. 3). Marketing competence cells act as an interface between customer and network. A possibility of connecting the marketing 
competence cell to product development competence cells is offered by Quality Function Deployment (QFD). QFD is a method for weighing customer requests and their further translation into a product requirements list. It is useful to determine the critical assemblies for the risk identification. The product requirements list represents the input parameter for product development. Together they decide if the project can be realized in the non-hierarchical production network with the methodical support of risk analysis. The risk traits, which are important in the different phases are shown in figure 3 and figure 4.

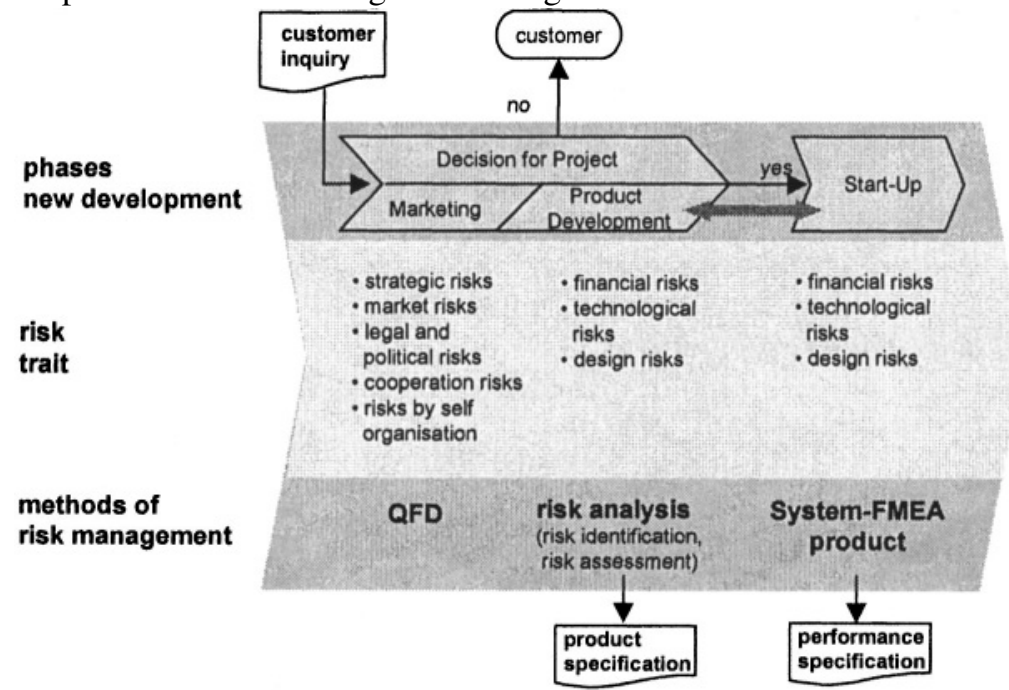

Figure 3 - Risk management in the product development process $(1)$

Figure 4 shows the following phases of the product development process. Financial, technological and design risks are evaluated in the planning and concept process and with the help of System FMEA measures are determined to minimise the risks.
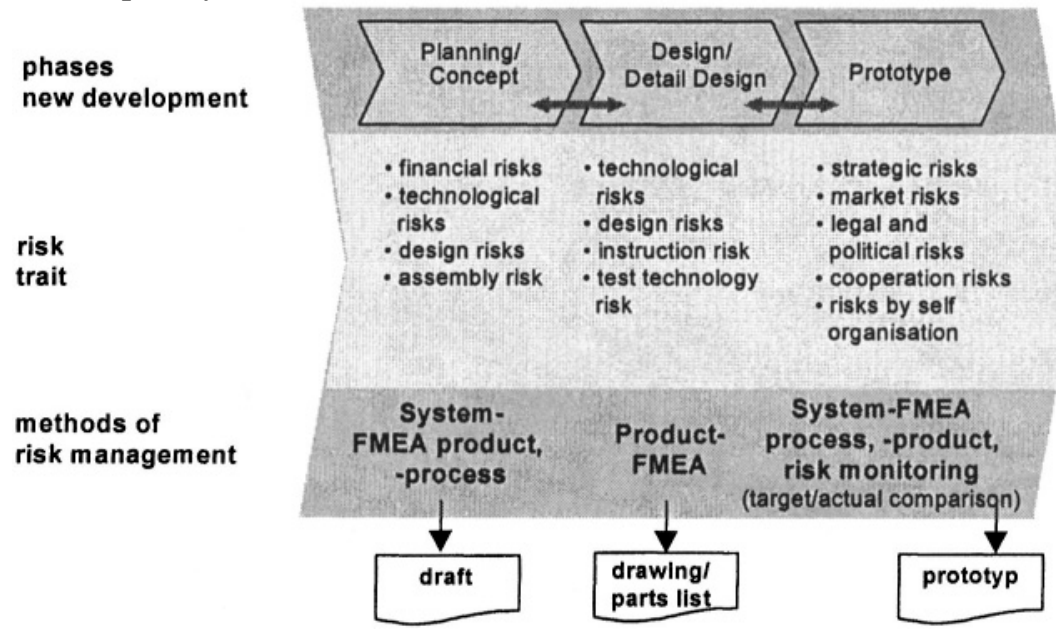

Figure 4 - Risk management in the product development process(2) 
The design and detailing stage is characterised by the risk assessment of the single parts.

Completing a risk monitoring is implemented in the prototype stage.

\section{SUMMARY AND PROSPECT}

The approach discussed in this paper constitutes a future-oriented and very promising survival strategy for the SMEs in a given region. By dividing the available expertise and resources into the smallest possible performance units in a logical structure, it will be possible in future to develop optimum innovative customer-specific solutions in the minimum amount of time in non-hierarchical production networks.

The objective is to build up a risk profile by uniform standards and values in a competence network, because the application of the risk management is more import in non-hierarchical structures. Standards and values influence the activity of the employees, and they therefore support the development of the units of competence and the competitive success. Risk management requires a functioning communication between the units of competence.

\section{REFERENCES}

1. Althaus, K., Dietzsch, M., Gerber, A.; Information Based, Dynamic Quality Information System for Non-Hierarchic Regional Production Networks, FAIM 2003, Tampa, Florida

2. Eversheim, W., Blomeyer, H., Riedel, H.: Projektmanagement in globalen Entwicklungs- und Produktionsverbünden - Das Spannungsfeld „Zentralisierung vs. Dezentralisierung” managen, wt Jahrg. 90 (2000) 5, S. 196-198

3. Neugebauer, R., Weidlich, D., Steiner, R.; Product Development in Non-Hierarchical Production Networks - a Competence-Cell-Based Approach to Solution, COMA'04, Stellenbosch, South Africa, 2004

4. Pfeifer, T., Simon, M.; Quality Services digital. Möglichkeiten des Einsatzes von IuK-Technologie in der QM-Beratung, QZ, Band 48 (2003) Heft 10, Seite 985-987

5. http://www.tu-chemnitz.de/sfb457/ 